\title{
An Analysis of Derivational and Inflectional Morphemes
}

Tahir Rasool Tariq (Corresponding author)

Riphah International University, Pakistan

E-mail: Tahir5050@gmail.com

Misbah Abid

The University of Lahore, Pakistan

Babar Sultan

The University of Lahore, Pakistan

Muhammad Asif

Riphah International University, Pakistan

Nida Rafique

The University of Lahore, Pakistan

Shehzad Aleem

Minhaj University, Lahore, Pakistan

Received: December 21, 2019

doi:10.5296/ijl.v12i1.16084
Accepted: January 11, 2020 Published: January 14, 2020

URL: https://doi.org/10.5296/ijl.v12i1.16084 


\section{Abstract}

This study highlights the analysis of Pakistani students for Derivational and Inflectional Morphemes at intermediate level. Derivational and Inflectional Morphemes are the elements which explores the field of morphology for daily language users. Morphology is the study of "morphemes". Morphemes are the smallest units of language that have described into two categories as free and bound morphemes. The main issue that exists in this study is to analyze the derivational and inflectional morphemes used by Pakistani students. Through the perceptions and understanding of inflectional and derivational morphemes, this study can produce the vocabulary in which one word have multiple meanings. This research paper is associated with linguistics and field of socio linguistics. This paper is purely based on qualitative research approach. In this study, the researcher founds the prominent dimensions caused by the inflectional and derivational morphemes, when attached with other morphemes. If the derivational morpheme is attached with free morpheme, it will convey different meaning and a chance have that it will change even word class. While inflectional morpheme will play a grammatical role when will be attached with free morpheme.

Keywords: Morphological, Derivational, Inflectional, Morphemes, Qualitative

\section{Introduction}

Language is a necessary and fundamental tool of communication. It is mandatory for language learners. This is essential part of learning that every person should be capable of mastery in main contents such as vocabulary, sentence structure as well as grammar. The fundamental units of language are employed in reference to synchronic linguistics for conveying that means. Morpheme is basic and smallest unit of a language (Lim Kiat Boey, 1975). The morphemes stand meaningfully alone are known as free morphemes whereas different morphemes like -ER and -ES, that cannot stand meaningfully alone are known as bound morphemes. Bound morphemes connected with free morphemes and are known as affixes, that are any sub-divided into prefix, infix and suffix. There are solely 2 sorts of bound morphemes like prefixes and suffixes. Infixes aren't found in English. In suffix phenomenon the affix is connected when a root (stem or base) as -LY, -ER, -OR, -IST, -S, -ING, and -ED.For instance: kind-ly, wait-er,book-s, walk-ed (Katamba, 1994).

Derivational morphemes and Inflectional are also considered as Morphemes. Furthermore, the acquiring process of inflectional morphemes is under the influence of two main school of thoughts; such as, dual-route and single-route. These are fundamental inflectional acquisition models. They provide information about grammar and the existing meanings of words to which they are associated. Bound morphemes are actually derivational morphemes which change the part of speech. These morphemes never change the syntactic state of the words to which it is associated (Bauer, 1988).

In English language derivational and inflectional morphemes can be prefixes or suffixes whilst they are connected to certain morpheme like -ness is referred to as derivational morpheme. A derivational morpheme produces a brand new lexeme from a base whilst inflectional morpheme does no longer accomplish that the researcher chooses the item and 
books due to the fact those assets provides one of the greatest media of information in Pakistan. It presents enough statistics about politics, economics, sports activities, education and leisure to the society as properly. Based totally on the above examine and factors, the researcher is goal to analyze the research.

The purpose of studies is to discover the varieties of derivational and inflectional morphemes, their features and the last however now not the least the rule of derivational and inflectional, English morphemes in Pakistani context. Therefore, this research paper goals to shed mild on cutting-edge issues by investigating whether Pakistani EFL newcomers are capable of use inflectional morphemes correctly or not. this research is based totally on reviewing the previous literature, there are a few research that have investigated the purchase of inflectional morphemes in English as a end result, this area nonetheless calls for in addition research and the present day study goals to fill this gap. Particularly, this have a look at will look at the viable reasons of studying inflectional and derivational English morphemes faced via the learners. the final aim of this have a look at is to discover the English talent degree of the learners plays a prime role in the comprehension of inflectional morphemes.

\section{Literature Review}

Study and Evaluation of previous research is especially crucial and critical either for selecting proper topic for research or to assist research paintings (boote and beile 2005). Researcher cannot perform enormous studies without first understanding the literature in that specific field (fink 2010). Literature overview is systematic, explicit and reproducible approach for figuring out, evaluating, and synthesizing current frame of finished and recorded work produced by way of researchers, students and practitioners.

According to idea of morpheme word which include textual content, cat and brief each conveys a pretty unmarried which means. The other words like a person, textbook and however encompass most important unit of meanings, they'll arise independently (some and one, text and book, how and ever). Besides, cats and quick additionally encompass main units (cat and $-\mathrm{s}$, short and - ly), but these words have simply one that means and can be used independently. It's far quite obvious that words do not constantly constitute the smallest Meaningful devices in a language. The smaller components are referred to as morphemes. it insistence that the collection be minimal guarantees that the morpheme cannot be divided into smaller units to which the a few definition would apply (martin at kinson and pals, 1982). John Lyons stated that, "such minimum units of grammatical-analysis, of word may be composed are usually referred to as morphemes" (introduction theoretical linguistics, 1986). The meaningful elements in a phrase are morphemes (Edward, 2003). For instance, real, unfaithful, without a doubt, truer, honest and so on. maximum morphemes have lexical which means, as with look kite and talk. Other one represent a grammatical category or semantic concepts such as past tense (the -ed in looked) or plural (the - es kites) or comparative degree (the -er in taller). 


\section{Theoretical Literature Review}

This paper was assisted with the aid of generative morphology concept that was added through Noam Chomskyin 1970, because it in generative grammar, the morphological concept marks on reading the linguistic regulations that can be applied inside the direction of producing an endless variety of words. Spencer (1994) argues that generative grammar seeks to provide an explicit, formal theory of language shape. At the start, this supposed building units of regulations, that are in the end formal is ready as mathematical expressions, But which in practice are usually said in a surprisingly informal notation. Such a fixed of guidelines is a grammar, and this is held to underlie the local speaker's tacit (subconscious) information of his/her language.

\section{Derivational Morpheme}

Derivational morphemes can be prefixes or suffixes in English. All prefixes are derivational in English. All prefixes modify the meaning although they do no longer adjust the syntactic class. for examples, the derivational prefix in- in inefficient, -un in undo and -re in rewrite, dis- in dislike and a- in amoral alternate the superb meaning to the poor meaning however do no longer modify the syntactic class of the derived words. Most derivational suffixes regulate each the syntactic category and the that means. Some of them do now not exchange the syntactic class most effective. The derivational suffixes which do no longer regulate the a part of speech are -ist in artist and dentist and -ism in terrorism and librarian.

\section{Inflectional Morpheme}

Inflectional morphemes are those which do no longer create any new meaning. These morphemes in no way regulate only the syntactic category of the phrases or morphemes to which they're connected (bauer, 1988). They simplest provide greater grammatical statistics approximately the already present which means of words to which they're connected. For example, the phrase books include a unfastened morpheme e book and an inflectional morpheme $-\mathrm{s}$. the certain morpheme-s does no longer adjust the syntactic class of the morpheme e-book. the bound Morpheme -s does now not most effective exchange the lexical meaning of e-book however offers just a grammatical meaning which shows that the word books is used as a plural. A book and books are nevertheless used as a noun.

\section{Problem Statement of Study}

The purpose of the study is to analyze Inflectional and derivational morphemes in Pakistani students.

\subsection{Objective of the Study}

To explore the functions of Inflectional and derivational morphemes in Pakistani students.

\subsection{Research Question}

What are the functions of inflectional and derivational morphemes in Pakistani students? 


\subsection{Significance of Study}

The advantages in this paper are divided into three parts: they are general advantages, specific advantages, and academic advantages

General advantage is that a common person will be able to understand affixation process in English language after reading this research. Second advantage is specific that means students can get more knowledge from this paper as compare to other persons of society. Third advantage of this paper is academic that will improve the knowledge in understanding the morphology that has been analyzed during by the student of intermediate level. The study of morphemes gives a great opportunity to understand the English language to English learners like a prefix, suffix, and root. The researcher hopes this paper can be utilized as additional knowledge to improve the ability in analysis of the problems, morphology and morphemes.

\subsection{Delimitations}

This research is only based on Sahiwal Division in the province of Punjab. Data was collected from the public sector (girls) colleges. The students from intermediate classes were included in the data collection. Data was collected from the students of the session 2018-2019.

\subsection{Population}

The population of the study consisted of all the public sector girl's colleges of Sahiwal division.

\subsection{Sample}

The sample of the study was collected through random sampling technique from 10 students of 05 different colleges of Sahiwal Division.

\section{Methodology}

\subsection{Data Collection}

Students were selected through random sampling technique. The data includes 10 different dialogues from the students of intermediate level on different topics. Each dialogue consists minimum 50 sentences.

\subsection{Data Analysis}

The data was analyzed through textual analysis. Textual analysis is a methodology that involves understanding language especially in inflectional and derivational morphology. The researcher has used the Information Extraction technique throughout from textual analysis. Textual analysis involves analyzing not just the content, but also the structure or design of a text and how elements function, often as part of a larger context. In the initial step of data collection, this research identified the English morpheme that collected from the source data. In the second stage of Information Erxtraction, the data that had some findings. In the third stage of Interpreting, the data found the functions of inflectional and derivational morpheme. 


\section{Macrothink}

International Journal of Linguistics

ISSN 1948-5425

2020, Vol. 12, No. 1

After describing the function and the principles of inflectional and derivational morpheme in English, Conclusion is the last stage that was used to answer the research question and achieved set of objectives of the study. Hence, this research is purely qualitative based research.

\subsubsection{Data Analysis of Dialogue 1}

Customer: I want two layer strawberry cake.

Shopkeeper: Do you want eggless cake?

Customer: Yes I want eggless.

Shopkeeper: Ok. But we make eggless on the orders. It will take minimum two hours. Either you can wait or you come by two.

Customer: O.k. no problem I will come by two but how much its cost for.

Qualitative Analysis:

According to selected students from the sample the above two lines of the sample from dialogue 1are according to inflectional and derivational English morphemes. The students used the word Eggless instead of without Egg. This is the trend which is prominent feature of this research. Students of intermediate level mostly used the word according to their profession rather than morphological rules.

In the fourth line of the sample, the student has used the word orders instead of rightly usage of word order because they are unaware from the morphology rules.

\subsubsection{Data Analysis of Dialogue 2}

Doctor: It's quite clear that the infection in your sinus is the reason for your headache. I'll prescribe an antibiotic to clear the infection and a pain killer to relieve the pain.

Patient: Thank you, doctor.

Qualitative Analysis:

In the sample dialogue 2, the doctor used the word "pain reliever" instead of "pain killer" according to profession of students. According to phenomenon of affixation, the word pain always associated with pain killer but students used it according to lack of knowledge in morphological rules. The word "prescribed" is written in a sample of line no. 1 is incorrectly used by the students' morphologically instead of the right usage of the word that is "prescribe."

\subsubsection{Data Analysis of Dialogue 3}

Line: 1 Interview Board: Which post have you applied for?

Line 2: Candidate: Market officer, sir.

Line 3: Interview Board: What is your educational qualification? 


\section{Macrothink}

Line 4: Candidate: B.A. Hons. in Economics. And I have postgraduate diploma in Market Management.

\section{Qualitative Analysis:}

In a Dialogue sample three, the students used the word "apply" rather than applied which is according to morphological rules -ED is a suffix when it is added to word, the addition of -ED is converted from first form to second form. A suffix is a letter or a group of letters. Which is usually attached to the end of a word to make a new form of word in affixation. In a second and fourth line of a sample, students did not add -ING to make it suffix and appropriate word according to morphological rules. Suffix -ING indicates present participle Form. The correct word is "Marketing" instead of "Market", the incorrect usage did not produce the actual sense of the sentence and did not convey the demanding meaning of the sentence. Student is unable to use affixation process in morphology because he is not much familiar from the morphological rules.

\subsubsection{Data Analysis of Dialogue 4}

Sunil - We take something as the security as their gold jewelry and their house.

Rahul - Ok but why do they take loans when they have houses and jewelry?

Sunil-Because of lack of liquidit .

Qualitative Analysis:

According to a dialogue Sample 4, the student used the Noun "house" incorrectly and did not add the suffix $-\mathrm{S}$ which did not create a true sense of a sentence according to morphological rules.

In the third line of the sample, the student did not use the Suffix $-Y$ in a word "Liquidity", which is the demand of morphological rules and without adding suffix-Y the word is not giving any sense.

\subsubsection{Data Analysis of Dialogue 5}

Kunnal- Yes, I am good at science .I learn it speedily even I do understand it but I do not like it. It is veryboring. I am interested in Paintings and want to do it only.

\section{Qualitative Analysis:}

In a dialogue sample five, the used correct use of suffix-LY which is quite fit according to rule of morphology. Adverb-forming suffixes are the Derivational suffixes which change the words or English morphemes to adverbs.

In the second line of the sample, the students used the word "very boring" correctly, which shows true depiction of derivational and inflectional morphological rules. In the word "very boring", the first part of a word "very" is prefix. The word highlights the intensity of the feeling of the student in choosing the word. 


\section{Conclusion}

"Morphemes are the smallest meaningful units of language." They are considered as meaningful unit because they perform a modification function to change the part of speech or grammatical meaning. Derivational morphemes in English can be prefixes and suffixes, on the contrary inflectional morpheme have suffix only. In this research, the researcher used different functions of morphemes and analyzed which derivational morphemes consist on prefix like -un, -in, -re -dis, and which derivational suffix consists on-er, -ment, -ful, ness, -tio/ion, - encelance, -able, -ity, -al, -ize, -ism, -ist, and ly and likewise inflectional morpheme consists on $-s$ or es, - 's, -er, -est, -ed, en, s or es and ing.

The research also found some basic function of derivational and inflectional English morphemes and their negative meaning, including as noun, as adjective, as verb, as adverb, plural mark, comparative, and superlative, present perfect form, past form, present participle and past participle. In the summing up part, the rules of the morphemes were analyzed. This concluding part describes that how the formation of the rules caused by combining bound morphemes and free morphemes and ultimately produced a new lexeme or new part of speech. The researcher also finds that findings of the study are according to the objectives. The researcher also hopes that this study will explore new techniques for the Derivational and Inflectional English Morphemes in near future.

\section{References}

Akande, A. T. (2001). Learners' competence versus morphological appropriateness in the acquisition of English language. Ife Studies in English Language, 5, 38-48.

Andrea, D. (2008). English Grammar Springer Science \& Business Media Finegan, Edward. Language Its Structure and Use, United States: Thomson Wadsworth.

Boey, L. K. (1975). An introduction To Linguistics. Singapore: Singapore University Press.

Francis, K. (1994). Morphology:Modern Linguistik. London: The Macmillan Press.

Geoger, Y. (2010). The Study of Language. City of Cambridge: Cambridge University Press.

John, L. (1968). Introduction to Theoretical Linguistics. London: Cambridge University Press.

Laurie, B. (1988). English Word Formation. City of Cambridge: Cambridge UniversityPress.

Louise, M., \& Stockwell, P. (2010). Introducing English language A Resource Book for Students. USA and Canada: Routledge.

Martin, A. (1982). Foundation of General Linguistics. London: George Allen \& Unwin.

Martin, H. (2002). Understanding Morphology (Understanding Language). Oxford University Press.

Muctar. (2007). Words, Meaning and Vocabulary: An Introduction to Modern English Lexicology. A\&C Black: England. 


\section{Macrothink}

International Journal of Linguistics

ISSN 1948-5425 2020, Vol. 12, No. 1

Nirmala, S. (1988). An Introduction to Linguistics Jakarta. Kementerian Pendidikan dan Kebudayaan.

Robert, L. (1964). Language Teaching a Scientific Approach. New York: McGraw-Hill, Inc.

Sabrony, R. (1986). Buku Materi Pokok Vocabulary Ping 4432/2sks/Modul 1-3. Jakarta: karunia Jakarta.

Sudaryatno. (1993). Metode dan Aneka Teknik Analisis Bahasa. Yogyakarta: Dutawa Wacana University Press.

Suharsima, A. (1998). Prosedur Penelitian Suatu Pendekatan Praktek. PT. Rineka Cipta: Jakarta.

\section{Copyrights}

Copyright for this article is retained by the author(s), with first publication rights granted to the journal.

This is an open-access article distributed under the terms and conditions of the Creative Commons Attribution license (http://creativecommons.org/licenses/by/4.0/) 